\title{
Interfaces of violence with and nursing education: a possible and necessary dialogue
}

Interfaces da violência com a formação em enfermagem: um diálogo possível e necessário Interfaces de la violencia com la formación en enfermería: un diálogo possible y necessário

Elisangela Argenta Zanatta ${ }^{1}$ (i) Thais Cristina Hermes ${ }^{1}$ Jean Henrique Krüger ${ }^{1}$ Peterson Luiz Duarte ${ }^{1}$ Carine Vendruscolo ${ }^{1}$ (i)

1. Universidade do Estado de Santa Catarina. Chapecó, SC, Brasil.

\section{Abstract}

Objective: To identify the professors' ideals and practices of undergraduate nursing education regarding the presence of violence during the teaching-learning process. Methods: Qualitative, descriptive and exploratory research, performed by 19 professors. For the collection of the information it had been used the Creativity and Sensitivity Dynamics. The data had been analyzed establishing its approximation with the referential present in Paulo Freire's works. Results: Violence is, on the theoretical and practical classes, problematized in an elementary way. The professors' actions are influenced by their experiences, however with a superficial critical reflection about practicing. Conclusion: The research reaffirm the need of investments in undergraduate nursing courses, mainly when dealing with issues such as violence, involving dialogue and attitudes based on lovingness enabling affective bonds and encouraging everyone to express themselves.

Keywords: Violence; Nursing Education; Nursing Care; Higher Education.

\section{Resumo}

Objetivo: Identificar o ideário e as práticas pedagógicas de educadores de cursos de graduação em enfermagem quanto à presença da violência durante o processo de formação. Método: Pesquisa de abordagem qualitativa, descritiva e exploratória, realizada com 19 educadores. Para a coleta de informações utilizou-se as Dinâmicas de Criatividade e Sensibilidade. Os dados foram submetidos à Análise de Conteúdo, estabelecendo sua aproximação com o referencial de Paulo Freire. Resultados: A violência é, nas aulas teóricas e práticas, problematizada de forma elementar. $O$ agir dos educadores é influenciado por suas experiências, porém com superficial reflexão crítica sobre a prática. Conclusão: $O$ estudo reitera a necessidade de investir na formação em enfermagem, sobretudo ao tratar de temas como a violência, envolvendo diálogo e atitudes pautadas na amorosidade, possibilitando vínculos afetivos e que todos sejam encorajados a se expressar.

Palavras-chave: Violência; Educação em Enfermagem; Cuidado de Enfermagem; Educação Superior.

\section{Resumen}

Objetivo: Identificar el ideario y las prácticas pedagógicas de educadores de cursos de graduación en enfermería cuanto a la presencia de la violencia en el proceso de formación. Método: Investigación cualitativa, descriptiva y exploratoria, con 19 docentes. Para la coleta de datos, se utilizó las Dinámicas de Creatividad y Sensibilidad. Los datos fueron sometidos al Análisis de Contenido, estableciendo su aproximación con el referencial de Paulo Freire. Resultados: La violencia es problematizada de manera elementar en las clases teóricas y prácticas. La acción de los docentes es influenciada por experiencias, pero con superficial reflexión crítica sobre la práctica. Conclusión: El estudio reitera la necesidad de invertir en la formación en enfermería, sobre todo al tratar temas como la violencia, involucrando diálogo y actitudes pautadas en la empatía, posibilitando vínculos afectivos y que todos sean estimulados a expresarse.

Palabras clave: Violencia; Educación en Enfermería; Cuidado de Enfermería; Educación Superior.
Corresponding author: Elisangela Argenta Zanatta. E-mail: elisangela.zanatta@udesc.br

Submitted on $02 / 09 / 2018$ Accepted on 06/27/2018.

DOI: 10.1590/2177-9465-EAN-2017-0404 


\section{INTRODUCTION}

Violence is a complex phenomenon, multidetermined and difficult to define, being it of polysemic nature that can be present in different situations of human coexistance. It consists in actions of physical order that can cause pain, suffering, fear, angst, lesions, mutilations, deformations or death. ${ }^{1}$ However, this phenomenon surpass physical damage, interfering, strongly, on victims' lives, according it's nature or type. Psychological violence is related to not fatal damages, presenting itself at workplace, schools and family context. It is also evidenced the prevalence of this type of violence in the most vulnerable human groups: women, children and adolescents. ${ }^{2,3}$

Beyond physical and psychological violence, sexual violence and negligence and abanoment are highlighted, which evidence deprivation of essential care. Sexual violence brings diverse consequences to victims in short and long term; including a bigger probability of depressive episodes and suicide to those who were sexually violated. ${ }^{4}$

The relationship between violence and health started to be considered, effectively, from 1996, from a Worldwide Health Assembly, in Genebra, that declared violence to be an important public health. In 2002, World Health Organization (WHO) emphasized a scientic approach to the issue with the elaboration of the World Report on Violence and Health, which classified the several types of violence, impacts and intervention used in different countries, proposing interventions to approach the phenomenon. ${ }^{5}$

In addition to the actions of the State in the face of violence, attention is drawn to the work of health and nursing professionals, who need to be aware of the problem, familiar with their different faces in order to feel secure in the face of the need to intervene to the phenomenon. However, scientific literature reveals that many arrive at health services with little or no preparation for recognition of violence and adequate referral of the victim. ${ }^{3,6-8}$ Beyond that, because of few knowledge, they act from their perceptions and professional or personal experiences, adquired in the process of living. ${ }^{6}$

Considering these considerations, health academics, especially in nursing, medicine and dentistry, reported difficulty in recognizing and, especially, providing interventions and care for victims of violence during practical activities. Part of this gap, evidenced on training, it's justified by the little training of educators in identifying the magnitude and consequences of violence for the health of the population. ${ }^{8,9}$

Related to nurses' specific training, National Council of Education/Higher Education Chamberr (CNE/CES) $n \div 3$, from november 7 th 2001 , article $3^{\circ}$, sigsn that the nurse must be capable to know and intervene about health-sickness situations, prevalent nationally, ${ }^{10}$ considering violence is an important determinant in the population's health. Nevertheless, it is imperative that the educator, as a member of the formation process, be awakened to the issue of violence, since he - professor - has important participation on developing critical conscience of learners, and the role of leadership in a power relationship that needs to be proactive and respectful, in which the leader grows through the growth of the group, in order to preserve the identity and uniqueness of all those involved. ${ }^{11}$ Hence the need for both - educator and learner - to engage in relationships devoid of pre-judgments and misconceptions about different issues, among which, violence.

The educator Paulo Freire comprehended education as an act of love, feeling in which men and women perceived themsevels as unfinished beings and, therefore, receptive to learning, in dialogic movements that are possible when an intense love emerge in the world and to men. It is not possible the pronouciation of the world, which is an act of creation and recreation, if there is not love as dialogue foundation, being love, therefore, also, dialogue. Pedagogical relationship, when surpass by affection, be love and by dialogicity, enables the development of education as liberty and humanization. ${ }^{11}$ By taking education as a political act and believing in dialogue and in lovingness as triggers of social transformation, Paulo Freire considers that there is no way to be people without being constantly involved in an educational process, conditioned to the fears, the imagination and the desires that make men beings in permanent search process. In this relationship between men, Freire identifies oppressors and the oppressed in all the scenarios of life. ${ }^{12}$

Based on the considerations considered and based on the referential of violence and the conception of education in Freire, as a possibility to contribute to the problematizing, political, dialogic and liberating formation, it was considered the need to investigate the context of professional training in nursing to violence, based on the presuppositions contained in his work. It is understood the problematization from a pedagogical, transformative and emancipatory conception, mediated by the constant interaction with reality, in which it is possible to transform and intervene through the development of the capacity to learn by doing. ${ }^{13}$

In this study, we used the WHO's concept of violence, which defines it as the use of force to strike oneself, the other or a group of people, being in a physical, psychological form or abuse of power, that intend or result in lesions, death, psychological harm, development deficiency or privation. ${ }^{5}$ The following research question was therefore outlined: how does violence present itself in the context of training in nursing? To answer it, we outlined the following aim: to identify the ideal and pedagogical practices of educators in the undergraduate courses of nursing as for the presence of violence in the context of training.

\section{METHOD}

Exploratory, descriptive and qualitative research, carried out in two Public Higher Education Institutions (IES) of Santa Catarina State. Higher education educators from undergraduated courses participated in the study. Inclusion criteria were: to be 
an educator of one of the undergraduate nursing courses and to be linked to the institution for more than one year, regardless of their original formation. Exclusion Criteria: educators away on leave or vacations at the time of information gathering activities.

An invitation to all educators was made electronically and printed, containing the objectives, date, time and place of production of the information. Of a total of 72 invited educators, 19 accepted to participate, being nine of one institution and ten of the other.

Information production occurred between the months of june and december 2015 through Criativity and Sensitivity Dynamics (DCS), advocated by the Creative and Sensitive Method (MCS). ${ }^{14}$ This method has its origin in Paulo Freire's problematizing pedagogy and seeks to unveil the research question, which is defined by the researcher and later reoriented by the collective discussions in the group. To this end, it privileges collective participation and values what emerges from the thinking and perception of participants. ${ }^{14,15}$

In order to organize the production of the information and in order to allow more space for dialogue with the participants, two groups were constituted: Group 1, IES-A; Group 2, IES-B. Meetings were held separately, one with each group, with an average duration of 60 minutes, keeping the same script in both.

To accomplish each meeting, five moments are necessary: "preparation of the environment and reception of the group; presentation of group participants; explanation of the dynamics and individual or collective work; presentation of productions; collective analysis and validation of data". ${ }^{14: 132} \mathrm{It}$ should be noted that in this research, MCS was only used as a strategy for the production of information, therefore, the analysis and collective validation step was not used.

At the first moment, the participants were welcomed in a warm, private, calm, noise-free environment, free from physical and mental risks. Chairs were organized in a circle for better interaction among participants. Outside the circle, the materials (sheets, colored pens, magazines, newspapers, glue, scissors) were arranged to carry out the activity.

At the second moment, the group was invited to introduce themselves, starting with the people who were conducting the information collection (two researchers, four auxiliary research students). Participants were offered the option to introduce themselves using their first name or the pseudonym. Then each one wrote his ID on a badge. The third moment consisted in explaining the dynamics of work. Following, three triggering questions were raised: What is violence to you? How do you perceive violence in the process of training in Nursing? How do you work this theme throughout training?

In order to conduct this stage, we chose to use DCS Free to Create, ${ }^{16}$ that is, each participant chose a way to register and present one's understandings from triggering questions. Some chose to cut and paste images that illustrated their understanding, others by drawing, others using words and phrases.
Information production and the unveil of the theme, occurred through the educators' discourse in the moment of presenting their production. This step is called codification. ${ }^{14}$ In the fourth moment, from the individual speeches of the participants, the group discussion began. During the discussions, the research assistants recorded in field diary the convergent and divergent themes, allowing them to be discussed by the group, dialogued and negotiated with the participants.

In order to close information production, it was considered the absence of new elements relevant to the subject matter, as well as the quantity and quality of information that allowed the scope of the recoding step.

The material for analysis was constituted of the speeches of the participants during the presentation of their production and of the collective debates. This material was submitted to Content Analysis, ${ }^{17}$ which is organized in four steps: pre-analysis, material exploitation, results treatment, inference and interpretation. On pre-analysis there is the floating, exhaustive reading, of the transcribed material aiming to organize it and choose what documents will be part of the analysis, respecting the following issues: completeness, representativeness, homogeneity and relevance. ${ }^{17}$

On material exploitation, tehre was the codification, comprehending the (selection of registration units), enumeration, classification and aggregation of intermediate categories and, later, of themes. On results treatment, there were inferences, interpretations and contextualizations from the referentials of violence and of Paulo Freire's works, that is, this step consisted in giving meaning to the results and interpret them, aiming to answer the objectives and discuss the results. ${ }^{17}$

The text was then organized into themes according to convergent and/or divergent ideas, with three categories for analysis and discussion: "nursing educators' ideology about violence: the objetification of the other"; "problematization of violence in nursing training"; "violence in the context of nursing: the consequence of personal, professional and training experiences".

With these designs, the present research was developed, based on conceptual and methodological, assumptions of liberating education. This practice allows a critical approach to reality, through its knowledge. The critical and dynamic way of seeing the world allows us to unveil reality, to discover what is mythological and to achieve the full realization of human work: the permanent transformation of reality into the liberation of men. ${ }^{11-13}$

The meetings were recorded in electronic form and later transcribed in full. The artistic productions were photographed with permission of the participants, who signed the Free and Informed Consent (TCLE). Research followed the guidelines proposed by Resolution 466/2012. It was approved by the Ethics Committee in feedback number 1.005.972 in March 30th 2015, (CAAE: 42937914.7.0000.0118). Participants were identified by the letter "T", from the word teacher, followed by an ordinal number. 


\section{RESULTS}

Average age of participants was 39 and average time in teaching, 12 years. Of 19 participants, 14 had a master's degree and five had a doctorate. About the specific training in violence, 14 said they didn't have training in the thematic, three reported they were self taught seeking materials on the theme, one of them worked in disciplines about violence during master's and stated that he did a short term course on the topic.

\section{Nursing educators' ideology about violence: the objetification of the other}

During the course of the DCS, teachers were questioned about what they understood by violence. Among the responses, we highlight the understanding of T11, which defines violence as the de-characterization of an individual, when the individual loses the identity of the subject and is reduced to an object.

Violence $[. .$.$] is the objetification of the other. It would be$ a bit of this: you don't treat the other as a subject (T11).

Others understand that violence has the characteristic of invading the space of another and preventing the exercise of freedom.

Violence is the act to violate a right, privacy and the other's individuality, to provoke damage to physical, mental or even social integrity of another, to prevent the right or the will of someone [...] (T16).

Violence is any act or any word that act in order to restrict freedom. It is not the liberty to do whatever I please, it's the freedom that goes until where the other's begin (T12).

In portraying the violence, T17, in his artistic production (Figure 1), makes an analogy with plantation, representing a situation from a larva feeding on a leaf.

[...] it's like that the issue of violence: there are always people eating from the outside in where we are; situations that do us harm and end up generating violence [...] that cause us, as a human being, can not grow and fruit in a way that we could transcend and bring good fruit (T17).

T18 understands that the violence happens from imbalances that are installed in the daily life of the teachers.

[...] I think that this issue of when we install these unbalances, situations of violence happen independently of which is your area or sector (T18).
Figure 1. Image of T17's production. Source: Investigation data, Chapecó, SC, Brazil, 2016.

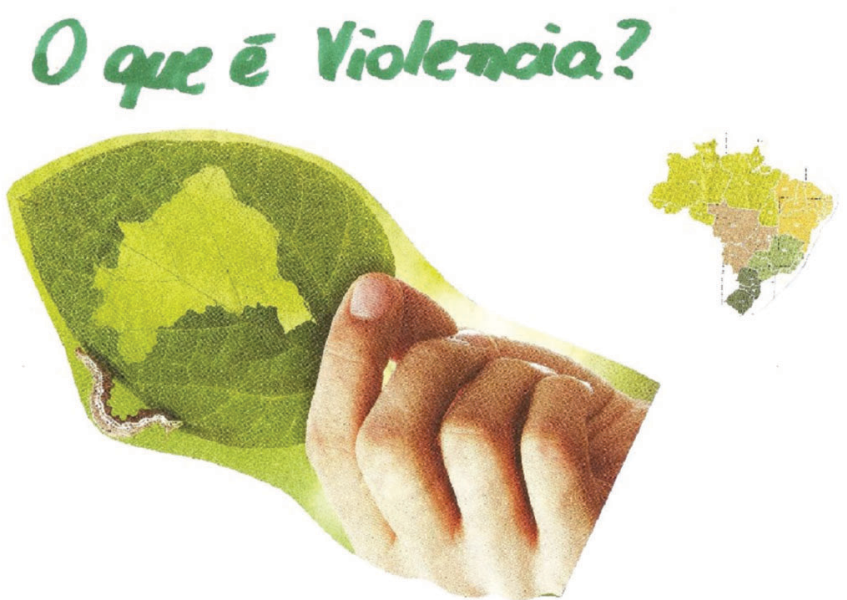

T10 understands the violence from the wars and dictatorships that mark the current society.

[...] violence to me is this war situation of intolerance that we have been living in the world [...] in particular because of the situation of Syrian refugees, the Palestinian army, or even issues [...] of Venezuela, the situation that sets in with dictatorship (T10).

[...] maybe people looking around see a situation of aggression because the environment is attacking people, by the political system [...], but maybe these people don't feel that way; maybe they feel confortable (T5).

[...] many times what's understood as violence to me is not understood as violence to the other (T7).

\section{Problematization of violence in nursing education}

In the course of the DCS, educators were questioned about how the approached and discussed the theme violence in different undegraduate contexts. Their arguments and productions showed that discussions occurred through violence cases witnessed, specially, in theoretical-pratical activities.

[...] I think that when were are theoretical-pratical class [...], this theme will always be present in a way or another, it's present and we end up working it, there's no running (T19).

[...] in relation to the theme, I don't work with it directly

[...] but we end up witnessing it and having a debate on $i t$, the discussion of practice [...] (T14).

In addition to a practical field approach, educators report that they work on the topic during theoretical classes, even if it is not 
included in the curricula of the nursing courses of the institutions and in the disciplines that are their responsibility.

[...] the Pedagogical Project of the Course [...] doesn't include violence as a theme. This doesn't prevent me from working it, but I still can't fit it in [...].We tried to accommodate, but the thematic violence itself, with its concepts and its types, I could not approach in my disciplines (T6).

[...] in the current PPC that we work at, it's invisible because I think the word violence doesn't appear once, however, there are a few initiatives to bring it to context during classes (T15).

Educators also exposed that commit violent acts with students and, even among them, there are inadequate moral attitudes. On doing this, they behave as living examples of human relationships.

[...] I think we commit violence much more than we teach it. We teach by example to people to be disrespectful because part of the assumption that we also teach by example, beyond the classroom and theory [...] (T11).

[...] What happens in the room is a reflection of what happens outside (referring to conflicts between educators). Students perceive our conflicting relationships, our way of being, how we act, the positive and negative aspects of our relationships (T4).

\section{Violence in the context of nursing: the consequence of personal, professional and training experiences}

When they were invited to reflect on the violence that permeates the daily routine of nursing education, the educators made the following reflections:

[...] we end up reproducing what we received in our training [...]because then you also put yourself in this relationship of power, teacher-student (T3).

[...] for example, in his academic experience, he saw scenes of verbal aggression, domination, power [...].When you put yourself in the teacher's chair, or suddenly the supervisor, the supervisor, or the manager, you can demonstrate or you can, perhaps involuntarily, do this by thinking that it was normal (T1)

Beyond this observation, educators also mentioned about their experiences, not necessarily from the educator-educating relationship, but those that express based on their experiences.
[...] everything that we have lived since childhood, our formation process and what we live in daily life, [...] influences our relationship with students and situations of violence (T4)

[...] violence is a consequence of the environment in which that individual is inserted and of the things that individual is carrying (T8).

In addition, educators also state that in some situations they have experienced, they have been in doubt as to whether or not they are rigid with academics, translating this rigidity as violence, sometimes even necessary for the learning process.

[...] I also think that some situations are inevitable, because we sometimes need to be rigid, which may be understood as a violent situation. But sometimes it is a necessary violence (T5).

You guide and understand all the difficulties of the student, [...] you try not to charge so much, not be rigid, not cause that suffering; only sometimes it does not go out [...] (T9).

[...] I try to act with great affection when I think I have to be, because I think the student's confidence with the teacher is important. But I think it has to be rigid as well, and I have to know how to be rigid, and this is not easy yet for me (T2).

\section{DISCUSSION}

To define violence is something very complex, because it's definition depends of a symbolism of what it represents for each person or group, which also influences on different ways to express it and comprehend it. By approaching violence from subjectivity, its pre-established definition becomes questioned, since it is possible for each to perceive violence in a different way, ${ }^{18}$ from their experiences in situations of violence.

Data make us think about the relations between oppressors and the oppressed, expressed in the work of Paulo Freire. For oppressors, humans are only them, the others are objects. Existance of oppressors and oppressed depends on how much oppressors control the oppressed, however, the more controled, the more they are transformed in objects. ${ }^{11}$ What makes men and women subjects of their story is the capacity to reflect about their situation, enabling them to commit themselves and act on it. This comprehension, however, is not possible when it's far from a liberating education, because it approximates the subjects to the condition of objects. ${ }^{19}$

Violence oppresses, curtails freedom, prevents man from acting, being the protagonist of his actions. Freedom is the possibility of the subject occupying the position of protagonist of his destiny, but for this, it is necessary to understand, how to be in 
each situation and able to act on it. ${ }^{11}$ Conflicts related to freedom can arise when, in seeking to exercise it, the individual occupies the space of the other, its limits and attacking its cultural issues. ${ }^{20}$

For Freire, ${ }^{19}$ being in the world implicates being with the world and with the others, therefore, subjects' relationships and with the world are inevitable, as the processes to reflect, evaluate, program, investigate and transform, which have an objective and are guided by the subjects' values. This way, relationships are inevitables and violence can exist, including, in the academic world, when a teacher, when acting according to their values, experiences and life history ends up affecting the student, corroborating the author's considerations. In this context, the author signs that critique enables to advance practice and theoretical reference, being needed to growth, a situation experienced during the DCS when teachers were invited to reflect on the existence of violence in their practices, to problematize their actions and to think about ways to minimize existing conflicts.

Violence is, also, tied to everyday actions may causing unbalacing and disruption of relationships, conditions these that, before the presence of violcence, can be still aparently, in harmony. According the literature about emotional and physiological aspects of violence, actions of this nature can cause unbalance in those that suffer desestructuring their basic human needs. ${ }^{21}$

However, some situations of violence, remembered by one of the participants who made an analogy with the larva that feeds on the leaf, preventing it from developing, can be evidenced in situations of bullying, presented in teaching instutitions practices by educators and learners. This type of violence transforms the learning envirorment in a hostile place, reducing the pleasure of teaching and learning from the actors involved. ${ }^{22}$

Still, on the participants' conception, wars represent one of the most important forms of homicide in mass in the world, as they are causes of severe damage to health of victims. In the same way, the dictatorship that is installed or was present in several countries, has a violent character, leading to homicides, damages and disappearance of individuals, as a way to oppress those who stand against the government. ${ }^{23}$ These situations of oppression, marked by death, discouragement and misery feed the existant unjust social order, in which oppressors seek and mantain their power from false generosity, mantaining the oppressed in their dependent position of the oppressor and without idealization of freedom. ${ }^{11}$

Research results also suggest the influence of culture on the ideology of violence. Man, as he determinates a culture, is also cultivated through relationships he stabilishes with the world and in the world. Culture, thus, is result of actions of man in view of its nature and the acquisition of the individual's own experience and those who surround him. ${ }^{19}$

For certain cultures, negative actions that lead to injury or death are considered violence, while those silent forms such as contempt, threat, disapproval, and abandonment remain naturalized. ${ }^{24}$
From the educators' speeches, it was manifested that violence depends on the envirornment and of people's awareness to see determined situations as violents. It is not possible that the subject fights against that he doesn't see as damage, without measure it's importance. Os sujeitos se sabem pisados pelos opressores, entretanto, a imersão na realidade não Ihes permite enxergar a si mesmos como oprimidos. ${ }^{19}$

Freire believed that human beings become social, critical and reflexive subjects through práxis, which consists in the approximation between action and reflection about the world, aiming to transform it. It is through práxis that men act consciously about reality, based on dialogue and relationships socially historic constructed. ${ }^{11,17}$ Therefore, for the oppressed to understand themselves as such, praxis must be present, allowing them to perceive the need to fight for liberation.

Different conceptions of violence presented can be translated as man responses facing situations they are exposed, influenced by culture that they are part of. Thus, also, nursing educators expressed themselves; from their awareness of situations that, at some point in their life, were experienced by them and that can influence their pedagogical relationship with the students.

To estabilish a pedagogical relationship based on reflexive dialogue implicates in the teaching-learning process..$^{13}$ On Freire's perspective, dialogue has a meaning because dialogic subjects not only preserve their identity but defend it, growing one with another. In this way, dialogue does not level, does not generate reductionism, but, on the contrary, fosters respect among subjects. ${ }^{11}$

In the context of nursing training, this relationship is marked out by behaviors and experiences, besides the assumptions that guide the "being nurse". However, for effective learning to take place, discussions and reflections must be guided by experiences, subsidizing students to face and position themselves in the face of reality as they enter the labor market. ${ }^{25}$ In this context, it is pointed out that the university is a propitious place for discussion of the theme of violence so that the future nurse can become an agent of transformation in the face of this phenomenon. For themes such as violence, it is recommended to use participative/active learning methods, anchored in real experiences of the student's daily life, favoring their protagonism.

Problematizing conception of education expresses this idea by basing itself on action and reflection, based on the reality of the subjects, allowing them to (re)create the world..$^{19}$ Learners are capable of reflecting about their actions and what they experienced in pratical field, raising questions about a new action and becoming protagonists of their learning.

It is believed that violence, treated by educators in a punctual form in some disciplines during the course, makes the learning process difficult for learners. In a brazilian nursing course, to include the theme violence against women in the curriculum, academics reported to understand this process as 
relevant, however, they evaluate the approach in a punctual way as liberating of it's deepening because it is not related to the practice. ${ }^{26}$ This situation corroborates the need to include this theme in nursing education in a broad and contextualized way with each reality, thus allowing the future nurses to be recognized for action and to respond to situations of violence that may arise.

Beyond that, to problematize violence from individual experiences observed in theoretical-practical activities, help learners and, at the same time, empower educators to understand it, because, at times, it's not clear that a gesture of his/hers, even if it seems insignificant, can have important representivity on the learner's training. Beyond that, academic accomplishment is influenced that the way the professor is perceived by what he says, associated to his conduct, being necessary, therefore, that he approach each time more the speaking with practice, so it doesn't convert itself to pure verbalism..$^{13}$

From the educators' point of view, it is considered that options of strategies to problematize the theme violence are by the practical, theoretical or practical examples of conduct, which are configured as the possibility of having the student reflect and elaborate their actions of possible situations of violence. Thus, it is not an eminent condition that violence appears in the PPC so that, only in this way, it is understood, however, it is evident the need for critical reflection of the educator on his teaching practice, transcending the naive vision until the apprehension of reality, in a epistemological posture about knowledge, making it a knowable object. ${ }^{11,13}$

This study's results are similar to other studies ${ }^{27,28}$ which reveal that educators suffer violence in the classroom, while children or, even though, in professional training, can reproduce as a professor's position, because violent situations in the school envirornment enable learners to reproduce the violence they are suffering. ${ }^{27}$

The teaching practice makes the whole formative process, experiences and the convictions of the teacher appear to the students, showing that the teacher can not detach from what he believes to be exclusively the teacher who dominates the content and brings to the classroom. ${ }^{28}$

The educator is not built exclusively by his learning during the formative process. Personal experiences and experiences influence your constitution as a teacher and how you act. This situations are expressed in Freire's works ${ }^{12}$ by considering that, when the individual rethinks his professional journey, he's based on his academic formation and his experiences of acting area. At times - and mistakenly - ignores his own presence in the world as influenciator of which he believes and follows, as his expectations, experiences and dreams didn't influence his professional journey.

While naturalizing their role of prescribing attitudes to academics, they understand that this way of acting can be understood as violence. Freire considers that "[...]every prescription is the imposition of the option of one conscience to the other [...]. The behavior of the oppressed is a prescribed behavior. It is made on the basis of strange guidelines - patterns of oppressors". ${ }^{11: 37}$ For this reason, the fundamental point for the need for the educator to feel obliged to be rigid may lie in the student's lack of understanding of what was constructed for him, and not with him. If the learner does not feel part of the process, the rigid requirements of the educators will recur, and this rigidity may constitute or generate situations of violence, depending on the understanding of those involved about the phenomenon.

The rigor of the work of the educator must be methodical in the way that the learners must travel in order to awaken the critical conscience. This is the professor role, aggregated the democratic educative practice, needing, because of this, to approach science and technique of qualities and virtues such as love, alterity, respect for the other and, above all, openess to the new, willingness to change, counteracting injustices. Affectivity needs to incorporate the pedagogical relation, therefore, only this way, it assures the development of the education like practice of the freedom and the humanization. That is why teaching and learning do not distance themselves from the demand, the good and the joy, without which the educational practice loses its meaning. ${ }^{13}$

\section{FINAL CONSIDERATIONS}

The ideology of undergraduate nursing educators about violence showed itself subjective and permeated by daily experiences. Reflections about violence, done in the classroom, can happen from the acadeic prerogative to contemplate the teaching plan or for a punctual necessity of approaching it in the classroom. Differently, the reflections that are carried out in the practice scenarios emerge from the need to dialogue about the theme as part of the reality experienced by both educators and learners.

Educator's ideology and attitude, thus, tangentiate and, at times, meets political and cultural pressumptions that are presented in the works of the educator Paulo Freire. This perspective enables reflections about the dialogue and autonomy and it's implication in interpersonal dialetic relationships in the university, which is also evidenced by a dialetic relationship between professor and student.

This study revealed that there are many challenges to be overcome, mainly, related to pedagogical practice, because of it it's indispensable the inclusion of the theme violence in nursing training, in diverse disciplines, following the discourse about care integrality, considering learners' autonomy, future health professionals, because transversality among knowledge and practices, as it's know, produces knowledge.

As limitation of the study, we recognize the impossibility of generalizing findings, considering qualitative methodology, therefore, the results found refer to subjects' journey and meanings. It is recommended to carry out new studies, in other scenarios, to deepen understandings that subsidize actions to recognize, minimize and reduce the presence of the phenomenon of violence in the context of nursing training. 


\section{REFERENCES}

1. Fiske AP, Rai TS. Virtuous Violence: hurting and killing to create, sustain, end, and honor social relationships. Cambridge: Cambridge University Press; 2014.

2. Abranches CD, Assis SG, Pires TO. Violência psicológica e contexto familiar de adolescentes usuários de serviços ambulatoriais em um hospital pediátrico público terciário. Ciênc Saúde Coletiva [Internet]. 2013 Oct; [cited 2017 Nov 22]; 18(10):2995-3006. Available from: http://www.scielo.br/scielo.php?script=sci_arttext\&p $\mathrm{d}=$ S1413-81232013001000024

3. Lima GHA, Sousa SMA. Violência psicológica no trabalho da enfermagem. Rev Bras Enferm [Internet]. 2015 Oct; [cited 2017 Nov 15]; 68(5):817-23. Available from: http://www.scielo.br/scielo. php?script=sci_arttext\&pid=S0034-71672015000500817

4. Modin TC, Cardoso TA, Jasen K, Konradt CE, Zaltron RF, Behenck MO, et al. Sexual violence, mooddisorder sand suicide risk: a populationbased study. Ciênc Saúde Coletiva [Internet]. 2016 Mar; [citado 2017 Oct 25]; 21(3):853-60. Available from: http://www.scielo.br/scielo. php?script=sci_arttext\&pid=S1413-81232016000300853

5. World Health Organization (WHO). Global status report on violence prevention 2014. Geneva: World Health Organization; 2014. [Internet] [cited 2017 Nov 6]. Available from http://www.who.int/violence_injury_ prevention/violence/status_report/2014/en/

6. Vieira EM, Hasse M. Perceptions of professionals in an intersectorial network about the assistance of women in situation of violence. Interface (Botucatu) [Internet]. 2017 Jan/Mar; [cited 2017 Oct 17];21(60):52-62. Available from: http://www.scielo.br/scielo.php?script=sci_arttext\&pid $=$ S1414-32832017000100052

7. Oliveira PS, Rodrigues VP, Morais RLGL, Machado JC. Assistência de profissionais de saúde à mulher em situação de violência sexual: revisão integrativa. Rev Enferm UFPE On Line [Internet]. 2016 May; [cited 2018 May 21]; 10(5):1828-39. Available from: https://periodicos. ufpe.br/revistas/revistaenfermagem/article/view/13563

8. Iftikhar R, Tawfiq R, Barabie S. Interns' perceived abuse during their undergraduate training at King Abdul Aziz University. Adv Med Educ Pract [Internet]. 2014 May; [cited 2018 May 21]; 5:159-66. Available from: https://www.ncbi.nlm.nih.gov/pmc/articles/PMC4041023/

9. Zanatta EA, Schneider AC, Kloh D, Vendruscolo C, Krüger JH, Hermes TC, et al. Violência no âmbito da formação em saúde: estudo bibliométrico. Rev Saúde UnG-Ser [Internet]. 2015; [cited 2017 Sep 2] 9(3-4):81-92. Available from: http://revistas.ung.br/index.php/saude/ article/view/2142

10. Ministério da Educação (BR). Conselho Nacional de Educação. Câmara de Educação Superior. Resolução CNE/CES № 3, de 7 de novembro de 2001. Institui Diretrizes Curriculares Nacionais do Curso de Graduação em Enfermagem. Brasília (FD): Diário Oficial da União; 2001. [Internet]. [cited 2017 Oct 10]. Available from: http://portal.mec. gov.br/cne/arquivos/pdf/CES03.pdf

11. Freire P. Pedagogia do oprimido. Rio de Janeiro: Nova Fronteira; 2012.

12. Freire P. Política e educação. $8^{\underline{a}}$ ed. Indaiatuba: Villa das letras; 2007.

13. Freire $P$. Pedagogia da autonomia: saberes necessários à prática educativa. 25ª ed. São Paulo: Paz e Terra; 1996.

14. Cabral IE. Uma abordagem criativo-sensível de pesquisar a família. In: Althoff CR, Elsen I, Nitschke RG, orgs. Pesquisando a família: olhares contemporâneos. Florianópolis (SC): Papa-livros; 2004. p. 127-39.
15. Soratto J, Pires DEP, Cabral IE, Lazzari DD, Witt RR, Sipriano CA. A creative and sensitive way to research. Rev Bras Enferm [Internet]. 2014 Nov/Dec; [cited 2017 Aug 10]; 67(6):994-9. Available from: http://www. scielo.br/scielo.php?script=sci_arttext\&pid=S0034-71672014000600994

16. Motta MGC, Pedro ENR, Paula CC, Coelho DF, Ribeiro AC, Greff AP, et al. Experiences of adolescent with HIV/AIDS. Rev Min Enferm [Internet] 2014 Jan/Mar; [cited 2017 Dec 06]; 18(1):181-7. Available from: http:// reme.org.br/artigo/detalhes/917

17. Bardin L. Análise de Conteúdo. 4ª ed. São Paulo: Edições 70; 2011.

18. Sarti C. A construção de figuras da violência: a vítima, a testemunha. Horiz Antropol [Internet]. 2014;20(42):77-105. Available from: http://www.scielo. br/scielo.php?pid=S0104-71832014000200004\&script=sci_abstract

19. Freire P. Conscientização: teoria e prática da libertação: uma introdução ao pensamento de Paulo Freire. São Paulo: Centauro; 2001.

20. Mattos AR, Castro LR. Jovens e a liberdade: reflexões sobre autonomia responsabilidade e independência. Psicol Soc [Internet]. $2016 \mathrm{Jan} / \mathrm{Apr}$ [cited 2017 Jun 28];28(1):65-73. Available from: http://www.scielo.br/scielo. php?pid=S0102-71822016000100065\&script=sci_abstract\&tIng=pt

21. Silva APAS, Pontes ERJC, Araújo OMR, Maggioni M, Barbieri AR, Togin JRF. Adolescente vítima de agressão: desequilíbrio nas necessidades humanas básicas. Rev Pesq Cuid Fundam [Internet]. 2013 Apr/Jun; [cited 2017 Nov 16]; 5(2):3749-56. Available from: http://www.redalyc. org/html/5057/505750898026/

22. Policy Paper 17: School-related gender-based violence is preventing the achievement of quality education for all. Paris: EFA Global Monitoring Report; 2015. [Internet]. [cited 2018 May 19] Available from: http:// unesdoc.unesco.org/images/0023/002321/232107E.pdf

23. Sanjurjo L, Feltran G. Sobre lutos e lutas: violência de estado, humanidade e morte em dois contextos etnográficos. Ciênc Cult [Internet]. 2015 Apr/Jun; [cited 2017 Jul 10]; 67(2):40-5 Available from: http://cienciaecultura.bvs.br/scielo.php?pid=S0009 $67252015000200013 \&$ script=sci_arttext

24. Ornellas MLS. Grito e silêncio: dois ecos que violam a escola. Estilos Clin [Internet]. 2012 Jun; [cited 2017 Oct 18]; 17(1):136-47. Available from: http://pepsic.bvsalud.org/scielo.php?script=sci_arttext\&pid $=$ S1415-71282012000100010

25. Clark CM, Ahten SM, Macy R. Using Problem-Based Learning Using Problem-Based Learning Scenarios to Prepare Nursing Students to Address Incivility. Clin Simul Nurs [Internet]. 2013 Mar; [cited Nov 2017 17]; 9(3):75-83. Available from: http://www.nursingsimulation.org/article/ S1876-1399(11)00248-9/fulltext

26. Rocha BD, Landerdahl MC, Cortes LF, Vieira LB, Padoin SMM. Violência contra as mulheres: percepção dos estudantes de enfermagem a respeito do enfoque na formação. Invest Educ Enferm [Internet]. 2015 May/Aug; [cited 2017 Aug 25]; 33(2):206-68. Available from: http://www.scielo.org.co/scielo.php?script=sci_arttext\&pid=S0120$53072015000200008 \&$ Ing $=p t \& n r m=i s o \& t \operatorname{lng}=p t$

27. Silva M, Silva AG, Diniz JE. O ECA e a violência na sala de aula vulnerabilidade da escola brasileira. Perspectiva [Internet].2015 May/Aug [cited 2017 Dec 30]; 33(2):789-803. Available from: https://periodicos.ufsc. br/index.php/perspectiva/article/view/2175-795X.2015v33n2p789

28. Junges KS, Behrens MA. Prática docente no Ensino Superior: a formação pedagógica como mobilizadora de mudança. Perspectiva [Internet]. 2015 Jan/Apr; [cited 2018 May 21]; 33(1):285-317. Available from: https://periodicos.ufsc.br/index.php/perspectiva/article/ view/2175-795X.2014v33n1p285/31220 